\title{
PENGARUH KEGIATAN BERMAIN DRAMA TERHADAP KECERDASAN INTERPERSONAL ANAK USIA DINI DI TK MUTIARA KENJERAN SURABAYA
}

\author{
Susiana \\ TK Mutiara Kenjeran Surabaya \\ Email : susiana1112@gmail.com
}

\begin{abstract}
ABSTRAK
Penelitian ini bertujuan untuk mengetahui bagaimana cara kegiatan bermain drama dapat mengembangkan kecerdasan interpersonal pada anak usia dini serta mengetahui kegiatan bermain drama dapat mempengaruhi kecerdasan interpersonal anak usia dini di TK Mutiara Kenjeran Surabaya. Penelitian menggunakan metode penelitian kuantitatif pre eksperimen desain one group pretes posttest. Teknik pengumpulan data menggunakan observasi, wawancara, dan dokumentasi. Sampel data yang digunakan dalam penelitian ini adalah peserta didik dari kelompok B di TK Mutiara Kenjeran Surabaya dengan jumlah siswa 15 anak. Teknik analisis data menggunakan uji Wilcoxon dimana metode statistika yang dipergunakan untuk menguji perbedaan dua buah data yang berpasangan. Hasil nilai pretest anak sebelum dilakukan perlakuan atau treatment memperoleh nilai rata-rata 25,5 yang menunjukkan perkembangan kecerdasan masih belum berkembang baik. Setelah mendapat perlakuan atau treatmen tanak-anak mendapatkan hasil ratarata 49 yang menunjukkan adanya perkembangan kecerdasan anak sudah mulai berkembang sesuai dengan harapan. Penghitungan dengan menggunakan uji wilcoxon menghasilkan $\mathrm{T}$ tabel = 25 dengan taraf kesalahan $5 \%$ atau 0,05 dan memperhatikan jumlah sampel penelitian. Jadi berdasarkan nilai $\mathrm{T}$ hitung $=0$ sedangkan $\mathrm{T}$ tabel $=25$, hal ini berarti nilai $\mathrm{T}$ hitung $<\mathrm{T}$ tabel . Penelitian ini menghasilkan kesimpulan bahwa penerapan kegiatan bermain drama dapat mempengaruhi kecerdasan interpersonal anak usia dini.
\end{abstract}

Kata kunci: kegiatan bermain drama; kecerdasan interpersonal; anak usia dini

\begin{abstract}
This study aimed to find out how drama playing activities could develop interpersonal intelligence in early childhood and understand its activities could affect on their interpersonal intelligence at Mutiara Kindergarten Kenjeran Surabaya. The study used quantitative research methods with pre experimental design one group pretest posttest. The data collection techniques were obtained by using observation, interview, and documentation. The sample data used in this study were 15 students from group B at Mutiara Kindergarten Kenjeran Surabaya. The data analysis techniques used the Wilcoxon test as the statistical method to test the differences in two pieces of data in pairs. The results of the pretest value of early childhood before applying treatment was an average value of 25.5 which indicated their intelligence development is still not well developed. After receiving treatment, they got an average results of 49 , which showed their intelligence development had begun to develop in line with expectations. The calculation used Wilcoxon test was $t_{\text {table }}=25$ with an error level of $5 \%$ or 0.05 and considered the samples. Thus, based on its calculation of $t_{\text {value }}=0$ while the $t_{\text {table }}=25$, this meant that $t_{\text {value }}<t_{\text {table. }}$. This research concluded that the implementation of drama playing activities could affect to early childhood's interpersonal intelligence.
\end{abstract}

Keyword: Drama Playing Activity; interpersonal intelligence; early childhood 


\section{PENDAHULUAN}

Anak usia dini memiliki ciri yang khusus dalam menunjukkan jati dirinya seperti keaktifan, dinamis dan antusias serta memiliki rasa ingin tahu yang besar terhadap apa yang didengar, dilihat dan dirasakan sebagai respon terhadap lingkungan sekitarnya. Menurut Izzaty (2017:6) menjelaskan bahwa rentang usia antara 4 sampai 6 tahun merupakan tahapan yang disebut usia prasekolah. Lembaga pendidikan prasekolah merupakan lembaga pendidikan yang membantu pertumbuhan dan perkembangan fisik dan psikologis anak yang berada diluar linkungan keluarga sebelum memasuki pendidikan formal dalam melatih anak-anak untuk beradaptasi dengan lingkungan yang baru dan penuh tantangan.

Kecerdasan interpersonal merupakan kemampuan dalam berpikir melalui komunikasi dengan orang lain. Kecerdasan ini meliputi kemampuan untuk bisa memimpin, mampu mengorganisasi, berinteraksi, berbagi, malakukan permainan kelompok, kerjasama, dan sebagainya. Kecerdasan ini perlu dikembangkan pada diri anak sejak usia dini karena kecerdasan ini mengenai cara anak menghadapi dunia luar atau orang lain maupun lingkungan diluar selain dari keluarganya. Apabila kecerdasan ini belum diasah dan tidak dikembangkan anak akan menjadi seorang pribadi yang pemalu, rendah diri, serta tidak mau berteman dengan teman sebayanya dan sulit untuk berkomunikasi dengan teman sebaya maupun orang dewasa disekitarnya. Anak dengan kecerdasan interpersonal ini akan memiliki kemampuan berinteraksi yang baik ketika berhubungan dengan orang lain, pandai menjalin hubungan sosial serta mengetahui dan mengunakan beragam cara saat berinteraksi. Mereka dapat merasakan perasaan, pikiran, tingkah laku dan harapan orang lain, serta mampu untuk bekerjasama dengan orang lain dan mudah memahami perasaan orang lain.

Pengamatan awal penelitian di TK Mutiara Kenjeran Surabaya kecerdasan interpersonal anak masih rendah, hal ini terlihat anak masih kurang dalam kemampuan memimpin, mengorganisasi, berinteraksi, saling bekerjasama, masih pemalu, kurang percaya diri, saling berbagi serta memuji hasil karya teman. Hal ini disebabkan karena kurangnya stimulus dan konsep pembelajaran yang monoton dalam pengembangan kecerdasan interpersonal ini melalui kegiatan yang telah dilakukan oleh sekolah. Berdasarkan permasalahan tersebut maka diperlukan solusi untuk memperbaiki masalah tersebut. Salah satu kegiatan untuk pengembangan kecerdasan interpersonal melalui kegiatan bermain drama. 
Kecerdasan interpersonal dapat dirangsang atau dikembangkan melalui kegiatan bermain drama sehingga anak akan memiliki kemampuan menjalin hubungan dengan teman sebaya melalui kerjasama dalam kelompok, memecahkan masalah dan menyelesaikan konflik melalui kegiatan bermain ini. Dalam bermain drama anak tidak dipaksakan untuk melakukan kegiatan yang diperintahkan tapi mengarahkan dan mengembangkan imajinatif anak untuk dapat melakukan peran yang anak inginkan sesuai dengan arahan dari pendidik.

Berdasarkan pendapat Vygotsky (dalam Winda, 2014) bahwa fungsi mental yang lebih tinggi berakar pada hubungan sosial dan kegiatan kerjasama. Kegiatan drama sangat sesuai karena memerlukan kerjasama didalamnya. Manfaat bermain drama dalam perkembangan adalah menyalurkan wujud ekspresi anak-anak kedalam kegiatan yang menyenangkan, mendorong berbagai aktivitas atau kegiatan, inisiatif atau ide dan kreatif sehingga mereka akan ikut serta berpartisipasi dalam kegiatan bersama, memahami isi cerita yang ada dalam drama karena ikut memainkannya, membantu dalam hal menghilangkan rasa malu, rendah diri dan kemurungan pada anak, mengajar anak untuk dapat saling membantu dan bekerjasama dengan teman dalam permainan drama, menimbulkan rasa saling percaya dan mempercayai satu sama lain antar anak atas kesanggupan masingmasing.

Adapun tujuan penelitian ini adalah: (1) Mendeskripsikan bagaimana cara kegiatan bermain drama dapat mengembangkan kecerdasan interpersonal pada anak usia dini di TK Mutiara Kenjeran Surabaya; (2) Mendeskripsikan kegiatan bermain drama dapat mempengaruhi kecerdasan interpersonal anak usia dini di TK Mutiara Kenjeran Surabaya.

\section{METODE PENELITIAN}

Jenis penelitian yang dilakukan dalam penelitian ini adalah menggunakan jenis penelitian kuantitatif dengan desain pre eksperimen one group pretest posttest. Desain One Group PretestPosttest merupakan desain dengan cara melakukan satu kali pengukuran didepan (pretest) sebelum adanya perlakuan (treatment) dan setelah itu dilakukan pengukuran lagi (posttest).

Penelitian ininbertujuan untuk mengetahui adanya pengaruh kegiatan bermain drama dapat mempengaruhi kecerdasan interpersonal anak usia dini dengan pengambilan sampel sebanyak 15 anak untuk kelompok usia 5-6 tahun.

Tempat penelitian ini dilakukan di TK Mutiara yang beralamat di Jalan Kalilom Lor Indah Gg Manggar no 2-4 Kelurahan Tanah Kali Kedinding Kecamatan Kenjeran Kota Surabaya khususnya pada anak didik usia 5-6 Tahun di TK Mutiara Kenjeran Surabaya. 
Waktu penelitian dilaksanakan selama 2 (dua) bulan yaitu bulan Desember 2018 sampai bulan Januari 2018. Sedangkan pengumpulan data dalam pelaksanaan penelitian ini peneliti menggunakan pengumpulan data dari hasil observasi langsung yang dilakukan terhadap anak usia dini di TK Mutiara Kenjeran Surabaya. Teknik pengumpulan data dalam penelitian ini adalah observasi, wawancara dan dokumentasi.

Analisis data dalam penelitian ini menggunakan ini menggunakan uji Wilcoxon dimana metode statistika yang dipergunakan untuk menguji perbedaan dua buah data yang berpasangan, maka jumlah sampel datanya selalu sama banyaknya (Sugiyono,2018) pada statistika parametrik uji ini memiliki kemiripan dengan uji perbedaan dua rata-rata populasi yang berkorelasi. Tanda positif dan negatif dari selisih pasangan data yang ada kemudian dirangking.

\section{HASIL PENELITIAN}

Data yang digunakan dalam penelitian mengenai kecerdasan interpersonal anak usia dini diambil dari hasil observasi yang terdiri dari 4 indikator diantaranya dapat bekerjasama dengan teman dalam melakukan kegiatan , memiliki rasa empati terhadap orang lain, terbiasa berbagi dengan orang lain, menunjukkan kemampuan peduli kepada orang lain. Observasi ini dilakukan ketika melakukan pretest dan posttest. Pretest dilakukan sebelum pemberian perlakuan (treatment) pada kelompok B2, sedangkan postest dilakukan setelah diberikannya perlakuan (treatment).

$$
\text { Pelaksanaan Pretest }
$$

dilakukan untuk mengetahui awal anak yang berkaitan dengan kecerdasan interpersonal anak sebelum dilakukan perlakuan (treatment). Penilaian pretest dilakukan satu kali melalui non test. Peneliti melakukan observasi tentang pengembangan kecerdasan interpersonal anak usia dini melalui kegiatan bermain drama secara sederhana. Kegiatan pretest yang dilakukan dalam pembelajaran fun day dimana anak melakukan kegiatan menirukan gerakan hewan di darat, dalam kegiatan menirukan gerakan hewan anak diberikan arahan untuk menirukan gerak hewan gajah berjalan, dalam kegiatan ini ada anak yang mampu melakukan ada anak yang terjatuh ketika melakukan.

Pelaksanaan Perlakuan

(Treatment) diberikan pada bulan Januari 2019 di TK Mutiara Kenjeran Surabaya. Perlakuan berupa kegiatan bermain drama yang dilakukan pada kelompok B2 melalui 3 kali treatment dengan menggunakan tema cerita sehari-hari berupa kegiatan drama dengan judul memancing ikan, banjir dipeternakan pak tani dan pergi ke kebun binatang. Hasil pretest dan posttest yang kemudian dimasukkan kedalam uji wilcoxon untuk mengetahui adanya pengaruh atau tidak dalam kegiatan bermain drama terhadap kecerdasan interpersonal anak usia dini. 
Dalam penelitian ini menggunakan uji Wilcoxon Match PairsTest untuk menguji hipotesis nihil $\left(\mathrm{H}_{\mathrm{o}}\right)$ yang mengatakan bahwa tidak ada pengaruh dalam kegiatan bermain drama terhadap perkembangan kecerdasan interpersonal.

Kriteria yang digunakan untuk menguji hipotesis nihil dalam penelitian ini adalah memakai taraf kesalahan $5 \%$ atau 0,05 .

$\mathrm{H}_{\mathrm{O}}=$ tidak ada pengaruh kegiatan bermain drama terhadap perkembangan kecerdasan interpersonal
$\mathrm{H}_{\alpha}=$ ada pengaruh kegiatan bermain drama terhadap perkembangan kecerdasan interpersonal Jika $\mathrm{T}$ hitung $<\mathrm{T}$ tabel maka hipotesis nol $\left(\mathrm{H}_{\mathrm{O}}\right)$ diterima Jika $\mathrm{T}$ hitung > $\mathrm{T}$ tabel maka hipotesis nol ( $\left.\mathrm{H}_{\mathrm{O}}\right)$ ditolak

Berikut penyajian data dalam tabel Wilcoxon Match Pairs Test

Tabel 1

Wilcoxon Match Pairs Test

\begin{tabular}{|c|c|c|c|c|c|c|c|}
\hline \multirow[t]{2}{*}{ No } & \multirow[t]{2}{*}{ Nama } & \multirow[t]{2}{*}{$\mathrm{X}_{\mathrm{A} 1}$} & \multirow[t]{2}{*}{$\mathrm{X}_{\mathrm{B} 1}$} & \multirow[t]{2}{*}{ Beda } & \multicolumn{3}{|c|}{ Tanda jenjang } \\
\hline & & & & & Jenjang & + & - \\
\hline 1. & Saajid & 8 & 13 & 5 & 4 & +4 & 0 \\
\hline 2. & Zil & 10 & 14 & 4 & 1,5 & $+1,5$ & 0 \\
\hline 3. & Amel & 9 & 13 & 4 & 1,5 & $+1,5$ & 0 \\
\hline 4. & Rizky & 5 & 12 & 7 & 10,5 & $+10,5$ & 0 \\
\hline 5. & Ragil & 6 & 12 & 6 & 7 & +7 & 0 \\
\hline 6. & Fayla & 9 & 14 & 5 & 4 & +4 & 0 \\
\hline 7. & $\mathrm{Al}$ & 8 & 14 & 6 & 7 & +7 & 0 \\
\hline 8. & Arya & 4 & 13 & 9 & 15 & +15 & 0 \\
\hline 9. & Nabila & 6 & 13 & 7 & 10,5 & $+10,5$ & 0 \\
\hline 10. & Feliz & 8 & 13 & 5 & 4 & +4 & 0 \\
\hline 11. & Habibi & 5 & 12 & 7 & 10.5 & $+10,5$ & 0 \\
\hline 12. & Nisa & 8 & 14 & 6 & 7 & +7 & 0 \\
\hline 13. & Qisya & 6 & 14 & 8 & 13,5 & $+13,5$ & 0 \\
\hline 14. & Iqbal & 4 & 12 & 8 & 13,5 & $+13,5$ & 0 \\
\hline 15. & Nadia & 6 & 13 & 7 & 10,5 & $+10,5$ & 0 \\
\hline \multicolumn{6}{|c|}{ Jumlah } & $\mathrm{T}_{+}=120$ & $\mathrm{~T}_{-}=0$ \\
\hline
\end{tabular}

Dari hasil analisis dapat disimpulkan bahwa hipotesis nihil $\left(\mathrm{H}_{\mathrm{o}}\right)$ yang menyatakan bahwa tidak ada pengaruh kegiatan bermain drama terhadap pengembangan kecerdasan interpersonal adalah tidak benar. Dengan demikian hasil analisis data yang mengacu pada hasil pretest dan posttest dapat menguji kebenaran hipotesis nihil $\left(\mathrm{H}_{\mathrm{o}}\right)$ yang ditolak sehingga menghasilkan kebenaran bahwa ada pengaruh kegiatan bermain drama terhadap pengembangan kecerdasan interpersonal anak usia dini pada 
kelompok B di TK Mutiara Kenjeran Surabaya.

\section{PEMBAHASAN}

Hasil analisis data yang terdiri dari data hasil pretest dan posttest yang kemudian dicari nilai selisih dari kedua proses tersebut, sehingga menghasilkan nilai jenjang yang menentukan Thitung untuk digunakan dalam menguji hipootesis nihil $\left(\mathrm{H}_{\mathrm{o}}\right)$. Hasil analisis data dengan menggunakan salah satu uji wilcoxon menghasilkan nilai $T_{+}$ sebesar 120 sebagai nilai selisih sementara $\mathrm{T}$-sebagai nilai $\mathrm{T}$ hitung hanya bernilai 0 , data $T_{+}$memiliki arti bahwa nilai selisih dari hasil pretest dan posttest mengalami perkembangan sedangkan data $T$. berarti nilai selisih antara kedua proses pengambilan data mengalami penurunan. Hal ini berarti ada pengaruh kegiatan bermain drama terhadap perkembangan kecerdasaan interpersonal anak usia ini.

Hasil wawancara yang dilakukan peneliti kepada guru mengungkapkan bahwa dalam kegiatan bermain drama tersebut anak-anak diarahkan untuk memahami alur cerita yang akan dimainkan dengan mengetahui peran masing-masing anak yang akan dimainkan. Guru tetap melakukan pengamatan terhadap anak yang diharapkan muncul karakter dalam pengembangan kecerdasan interpersonal sesuai dengan indikator yang telah ditentukan dalam tema tersebut. Kegaiatan diakhiri guru mencoba menggali dan menanyakan karakter-karakter yang muncul dalam diri anak ketika melakukan kegiatan drama yang telah dilakukan.

Hasil analisi data diatas tersebut juga dapat membuktikan teori yang dikemukakan oleh Smilansky (1971) menyimpulkan bahwa kegiatan bermain drama membangun tiga area penting pada diri anak, tidak hanya bermain tetapi juga permainan atau simulasi sekolah dan permainan atau simulasi kehidupan. Ketiga aspek itu akan menumbuhkan yang pertama yaitu kreativitas, berdasarkan pengalaman yang sudah dilalui anak dan dikendalikan dalam bingkai kerja skenario yang direncanakan bersama guru dan anak dengan cara mendiskusikan dan menggali ide-ide dari anak-anak sehingga memperkaya ide besar menjadi satu pemahaman yang sama. Aspek yang kedua dapat mengembangkan intelektual dan bahasa, dalam kegiatan drama anak mengabstraksi, memperkaya konsep dan mendapatkan pengalaman baru dengan bebas menggunakan bahasa sehingga kemampuan berbahasa anak cepat berkembang. Aspek yang ketiga yaitu ketrampilan sosial, dalam kegiatan bermain drama mengandung nilai-nilai positif tentang "memberi dan menerima", toleransi dan kebijaksanaan. Ketrampilan sosial terbangun dalam episode kehidupan keluarga dan masyarakat, dimana anak harus hidup bekerja sama dengan manusia lain dalam mencapai tujuan bersama. 


\section{KESIMPULAN}

Berdasarkan hasil analisis data bahwa kegiatan bermain drama memiliki pengaruh dalam mengembangkan kecerdasan interpersonal (kemampuan berinteraksi) pada anak kelompok B di TK Mutiara Kenjeran Surabaya sebagai berikut:

1. Kegiatan bermain drama dapat mempengaruhi perkembangan kecerdasan interpersonal anak usia diniterlihatdalam hasil nilai pretest anaksebelum dilakukan perlakuan atau treatment memperoleh nilai rata-rata 25,5 yang menunjukkan perkembangan kecerdasan masih belum berkembang baik. Setelah mendapat perlakuan atau treatmentanak-anak mendapatkan hasil rata-rata 49 yang menunjukkan adanya perkembangan kecerdasan anak sudah mulai berkembang sesuai dengan harapan. Penghitungan dengan menggunakan uji wilcoxon menghasilkan $\mathrm{T}$ tabel $=$ 25dengan taraf kesalahan $5 \%$ atau 0,05 dan memperhatikan jumlah sampel penelitian. Jadi berdasarkan nilai $\mathrm{T}$ hitung $=0$ sedangkan $\mathrm{T}$ tabel $=25$, hal ini berarti nilai $\mathrm{T}$ hitung $<\mathrm{T}$ tabel sehingga terdapat pengaruh kegiatan bermain drama dalam mengembangkan kecerdasan interpersonal anak usia dini

2. Kegiatan bermain drama yang dapat mengembangkan kecerdasan interpersonal ini yang dilakukan dapat menunjukkan kemampuan bersosialisasi anak dengan teman sebaya sehingga memiliki rasa empati terhadap orang lain, mampu bekerjasama dengan teman dalam melakukan kegiatan, dapat berbagi dengan orang lain serta menunjukkan kemampuan rasa peduli kepada orang lain yang kita harapkan muncul dalam diri anak.

\section{SARAN}

Berdasarkan hasil penelitian yang telah dilakukan maka peneliti memberikan saran yang sesuai dengan tujuan penelitian yaitu sebagai berikut:

1. Perkembangan kecerdasan interpersonal yang merupakan perkembangan kemampuan menjalin hubungan dengan teman sebaya hendaknya menjadi salah satu perhatian guru dalam memuat materi pembelajaran karena dengan memiliki kemampuan menjalin hubungan atau komunikasi dengan orang lain yang baik peserta didik akan dapat mendapatkan banyak bekal penting dalam mempersiapkan diri anak untuk memasuki ke jenjang selanjutnya.

2. Adanya bukti bahwa kegiatan bermain drama memiliki pengaruh yang signifikan terhadap perkembangan kecerdasan interpersonal anak, diharapkan guru dapat melakukan kegiatan bermain drama atau peran yang dikemas dalam naskah drama yang menarik dan mudah dipahami karena dapat dijumpai 
anak-anak dalam kehidupannya sehari-hari.

\section{DAFTAR PUSTAKA}

Aisyah, Siti, dkk. (2017). Perkembangan Dan Konsep Dasar Pengembangan Anak Usia Dini. Tangerang Selatan : Universitas Terbuka.

Arikunto, Suharsimi. (2014).

Prosedur Penelitian. Jakarta : PT Rineka Cipta.

Gunarti, Winda. (2014). Metode Pengembangan Perilaku Dan Kemampuan Dasar Anak Usia Dini. Tangerang Selatan : Universitas Terbuka.

Indra Soefandi dan Ahmad Pramudya. (2009). Strategi Mengembangkan potensiKecerdasan Anak.
Izzaty, Rita Eka. (2017). Perilaku Anak Prasekolah. Jakarta: PT Elex MediaKomputindo.

Mulyani, Novi. (2018). Perkembangan Dasar Anak Usia Dini. Jogyakart:Gava Media.

Musfiroh, Tadkiroatun. (2015). Pengembangan Kecerdasan Majemuk. Tangerang Selatan: Universitas Terbuka.

Sugiyono. (2016). Metode Penelitian Kuantitatif, Kualitatif dan $R \& D$. Bandung: Alfabeta.

Sugiyono. (2018). Metode Penelitian Kuantitatif. Bandung : Alfabeta.

Triwiyati, Atik. (2017). Asyiknya Bermain Peran. Solo:Tiga Serangkai. Cetakan pertama: Agustus. 